\title{
The Future of Library Service and Education for Librarianship
}

BY FRANK L. SCHICK

$\mathrm{W}$ HEN Library Trends was launched in July 1952, Robert Downs wrote in the introduction to the first issue that "it was the consensus of advisors that library science has reached a stage in its growth where synthesis and interpretation are required. . . . In no existing organ, however, has one been able to secure a well-rounded view of the state of progress of any particular area of librarianship. No source has brought together widely scattered fragments into a coherent and connected whole. It was agreed, accordingly, that this sort of integration should be the primary aim of Library Trends. ... In substance the purpose is to offer a general status quo statement of social, political, educational, and economic tendencies now affecting libraries, with some forecasts of things to come and attempts to identify areas in need of further investigation." 1

Nine years after the first issue, the goals and purpose, so well chosen, remain unchanged, but several departures were made in the July and October 1961 issues.

Emphasis is shifted from status quo to forecasting. In attempting to look ahead it is essential to base our crystal gazing on the solid foundation of the 1960 census data. Since statistical projections belong to a discipline outside the librarian's province we were fortunate to secure the assistance of Philip M. Hauser, chairman, department of sociology, and director, population research and training center of the University of

1 Robert B. Downs,: "Introduction," Library Trends, I (1952), 3 .
Dr. Schick is Assistant Director, Library Services Branch, Office of Education, Department of Health, Education, and Welfare.

Chicago, and former deputy director of the U.S. Census Bureau, to join our team of distinguished librarians and specialists, in a field already familiar to him. ${ }^{2}$

In dealing with all types of libraries and several areas cutting across the institutional aspects, such as their human and material resources, the task grew beyond the confines of one issue.

While Library Trends can look back on the tradition of obtaining the best of professional writing without compensation, the demands made on Dr. Hauser for tabulations and charts required assistance which had to be remunerated.

The Council on Library Resources provided two grants which permitted the preparation of the supporting materials. Departing again in the preparation of Library Trends from the established custom, it seemed important to coordinate the work of our twenty contributors not just through correspondence but to arrange for two meetings which would permit the authors to indicate to Dr. Hauser what particular subject fields his projections should cover. Travel funds for these conferences were provided for a number of participants by a grant from the Grolier Foundation. As a result, $L i$ brary Trends became for the first time the grantee of two foundations. This fi-

2 Philin M. Hauser: "Community Developments and Their Effects on Library Planning," Library Quarterly. XXVII $(1957), 255-56$. 
nancial assistance assured the publication of our issues.

The first contributors' meeting was held in October 1960 in the U.S. Office of Education in Washington, the second in January 1961 at the Edgewater Beach Hotel in Chicago preceding the 1961 ALA Midwinter meeting. Active participants in the meetings and resource personnel sans pareille were my colleagues in the LSB: Herbert A. Carl, Nathan M. Cohan, Mary Helen Mahar, John Carson Rather, and Rose Vainstein.

To cope with the materials in two issues with different deadlines and to present the profession's viewpoint to the American public, which could be written only by the executive officials of the American Library Association, it was decided to approach the subject in three stages:

1. The preparation of Dr. Hauser's lead article and supporting materials which form the bases for the elaboration of the subject specialists (together with the Introduction published as Part $I$ in the July 1961 issue).

2. The articles of the subject specialists.

3. The summary section of David $\mathrm{H}$. Clift and Germaine Krettek (Items 2 and 3 published as Part II in the October 1961 issue).

The preparation of the two issues, including editorial arrangements, the selection of topics, and the selection of authors took two years. How sincere the profession's cooperation was is evidenced by the acceptance of writing assignments at the first invitation by all but four authors.

Independent of this project, the Library Services Branch obtained authorization in 1960 from the Office of Education to cosponsor with Western Reserve University an institute on education for librarianship, to study areas of mutual concern to faculty members of library schools and practitioners in the field. In December, Jesse $H$. Shera, Ruth Warncke, John G. Lorenz, and this writer discussed the manner of presentation including the preparation of preconference papers. At this meeting, it was suggested that the July and October 1961 issues of Library Trends be used as conference working papers. With the approval of Harold Lancour and the contributors, this added use of the issues has been incorporated in the institute's program.

The Institute on the Future of Library Education, Demographic Aspects and Implications, is scheduled for April 1962 in Cleveland. It will be directed toward an exploration of needed adaptations in emphasis and subject content in the programs of study, research activities, and curricula of library schools through anticipated changes in the demographic, social, and economic conditions.

The Institute will bring together between 100 and 125 librarians and library administrators from school, college, university, public, and special libraries and faculty members of library schools to plan joint programs. The three-day institute will consist of addresses and symposia stressing the impact of demographic changes on the individual, social institutions, and educational policies, and their effect on library services, their organization and institutional interrelationships.

The general sessions will be followed by group meetings which will consider detailed aspects such as library personnel, requirements for future services, admission requirements, and types of degrees to be conferred. Each of the groups will work on different aspects of the recommendations, which will be submitted to the attendants for adoption. The Journal of Education for Librarianship will publish in a special issue the papers and the recommendations of the institute.

To assist participants and discussion leaders, a conference workbook and background material will be prepared and sent in advance to all registrants. 